\title{
FACTORS AFFECT CUSTOMER SATISFACTION: THE CASE OF CARGO DELIVERY SERVICES
}

\author{
Phuong Viet Le-Hoang \\ Ho Chi Minh City Open University, Vietnam \\ E-mail: lehoangvietphuong@gmail.com
}

Submission: 7/19/2019

Revision: 9/18/2019

Accept: 10/2/2019

\section{ABSTRACT}

The research aims to explore and measure the factors affecting customer satisfaction in cargo delivery services in Vietnam. Notably, the researchers develop a new scale to examine the effect the customer satisfaction, and it is the price factor. To conduct the research, the authors do group discussions and expert discussion and then analyzed 1,729 valid respondents with five factors: resource, service capacity, management capacity, brand reputation and price. The result from Exploratory Factor Analysis (EFA) shows that all of the independent variables have a significant effect on customer satisfaction. In which, brand reputation is the most influential factor, and the management capacity is the least influential factor. Besides, the research shows that the price also effects on customer satisfaction on cargo delivery context. Based on that, the research recommends the necessary management solutions to increase customer satisfaction, and it also supports the new scale and ideas to research in the new field and new country in further research.

Keywords: resource; service capacity; management capacity; brand reputation and price; customer satisfaction. 
DOI: 10.14807/ijmp.v11i4.1103

\section{INTRODUCTION}

According to the Logistics Business Association (2018), Vietnam has over 1,300 active enterprises in the logistics industry, including foreign enterprises. The enterprises providing logistics services in Vietnam are mostly small and medium-sized. The total revenue from logistics services in Vietnam, it is about 20-22 billion USD/year, accounting for $20.9 \%$ of the country's GDP. According to the World Bank Report (2018) on the Logistics Performance Index (LPI), Vietnam ranked 39/160 countries participating in the study, and rose to the 3rd place in ASEAN countries. Vietnam is also a top-ranking country in emerging markets. It is the best result that Vietnam has achieved since the World Bank has been performing LPI ratings since 2007 up to now.

In the context of global economic integration, when Vietnam has opened the doors to the service sector, Vietnamese delivery businesses have to compete with foreign enterprises. In fact, among the world's top 30 delivery companies, 25 corporations are entering the Vietnamese market, accounting for $75 \%$ of the market share, mainly in the areas of the high added value. On the contrary, with about a quarter of the market share being narrow and difficult, domestic enterprises must seize each opportunity. Not only that, the capacity of Vietnamese delivery enterprises is limited because the quality of services cannot compare to foreign enterprises.

In order to affirm its position as well as to achieve outstanding development in the future, and in addition to making efforts to provide delivery services with the lowest cost, measuring customer satisfaction on quality of delivery of companies in Vietnam is really necessary to assess the impact of service quality factors affecting customer satisfaction and providing solutions to improve the quality of delivery services. This study was conducted in Vietnam on a large sample size to analyze the factors affecting cargo delivery services.

\section{LITERATURE REVIEW AND HYPOTHESES DEVELOPMENT}

\subsection{Concepts}

\subsubsection{Service quality}

From the unique characteristics of the service, it makes a difference in determining the quality of service. For tangible products, its quality is measured by specific criteria such as features, durability, characteristics, and so on. However, for the service, it is invisible, so the quality of service is also invisible. Therefore, the quality of service is assessed in the process of using service, and the process of interaction between companies and customers using 
DOI: 10.14807/ijmp.v11i4.1103

service. Besides, Lehtinen and Lehtinen (1982) argue that there are two respects can assess the service quality; the first is service value, and the second is service outcome.

According to Parasuraman et al. (1988), service quality is the level of difference between consumer expectations of services and their perceptions of service outcomes. The SERVQUAL model of Parasuraman et al. (1988) has applied and tested in practice by many researchers in many service sectors in different markets such as Bojanic (1991) with audit services, Cronin and Taylor (1992) with dry cleaning services, Dabholkar (1996) for retail services.

In short, the quality of service through each stage is defined in a general way: service quality relates to customer expectations and their perceptions of the service. Every customer with different perceptions and needs will have a sense of different service quality.

\subsubsection{Customer satisfaction}

Customer satisfaction is a crucial part affecting the success of every business in any business field (KOTLER, 2001). In an increasingly fierce competitive environment, especially those that provide services, to maintain the growth, the company needs to satisfy customers' needs. Because customer satisfaction is essential in establishing long-term relationships between customers and service providers, the reality of business shows that, if an enterprise gains $5 \%$ of loyal customers, the profit will increase by $25-85 \%$, or on average an unhappy customer will tell the discomfort to 9 listeners, and one satisfied customer will tell 5 others about the good feelings about the products and services of the business. Therefore, when a business does not satisfy customers, it is not only businesses that lose customers but also lose many potential customers (KOTLER; KELLER, 2016).

According to Oliver (1997), customer satisfaction is an emotion of customers in response to their experience with some products and services. Alternatively, satisfaction is the reaction of consumers to estimating the difference between previous expectations (or standards for performance) and the actual expression of the product when using it (Tse and Wilton, 1988).

\subsubsection{The relationship between service quality and customer satisfaction}

According to Pitt et al. (1995), the relationship between satisfaction and service quality is an essential key to measuring the satisfaction of service of the customers. Also, Bhatnagar et al. (1999) also pointed out that that customer satisfaction is a crucial benefit to the quality of logistics services. 
INDEPENDENT JOURNAL OF MANAGEMENT \& PRODUCTION (IJM\&P)

http://www.ijmp.jor.br

v. 11, n. 4, July - August 2020

ISSN: 2236-269X

DOI: 10.14807/ijmp.v11i4.1103

Other researchers, such as Parasuraman et al. (1988), Zeithaml and Bitner (2000), offer that customer satisfaction leads to service quality. However, Cronin and Taylor (1992) argue that service quality is the cause of satisfaction because the quality related to service and satisfaction only assessed after the customer uses the service. If improving service quality is not based on customer demand, it will not satisfy customer demand for that service.

Overall, customer satisfaction has a causal relationship with service quality. If the service quality is too high, the level of satisfaction exceeds expectations. Quality of service is high, and the satisfaction level reaches the expected level, customers feel happy and satisfied. Conversely, if the service quality is low, the satisfaction level is lower than the expected value, the customer will be disappointed. Customer satisfaction is a general concept, expressing their satisfaction when consuming a service. Meanwhile, service quality only focuses on specific components of the service (ZEITHAML; BITNER, 2000).

\subsection{Research model and hypothesis development}

From the theoretical concepts and analyses presented above, there are many research models on the relationship between service quality and customer satisfaction. So, the question is that what is the most suitable model for research in the cargo delivery context? There are some models of service quality such as SERVQUAL (reliability, responsiveness, assurance, empathy and tangibles) of Parasuraman et al. (1988), SERVPERT - the development model of SERVQUAL (CRONIN; TAYLOR, 1992), ROPMIS (resources, outcomes, process, management, image, social responsibility) of Thai and Grewa (2007).

The ROPMIS model is most appropriate because of three reasons. Firstly, the model is derived from the theoretical synthesis of many different models. Secondly, the construction of the original ROPMIS model is implemented in the specific context of the Vietnamese transport industry. While other models are mostly tested in other industries, it shows that the application of ROPMIS model is appropriate because it is very close to the scope of the quality of freight forwarding research. Finally, although the ROPMIS model is not yet widely applied, research using this model has shown positive results. Some empirical researches have applied ROPMIS model, specifically: Research of Tran (2010), Nguyen and Do (2013) and most recently, Yuen and Thai (2015) directly concerned with research.

However, the factors affecting satisfaction changes depending on the context, type of service, and specific type of business. Therefore, in order to determine the determinants that affect the satisfaction of customers using delivery service in cargo company, the study has 
DOI: 10.14807/ijmp.v11i4.1103

shown that resource, service capacity, management capacity, and brand prestige are four factors affect the satisfaction.

Besides, perceived value is the trade-off of what customers receive (quality, benefits, usefulness) and what they spend (price, sacrifice, and time) to buy and consume these products and services. According to Zeithaml and Bitner (2000), customer satisfaction is affected by customer perceptions of quality. According to Fornell et al. (1996), customer satisfaction is the result of a perception of their perceived value, while the value is measured by the relationship between perceived service quality and service price.

Based on these points of view, it can be said that the satisfaction of customers with the perception of service prices is related to each other. Customers will be satisfied with the service when they are more satisfied with the price. Therefore, the author proposes the price factor in the research model. This study defines and measures the concept of service pricing from the perspective of customers' perception of prices.

Based on the above arguments, the author proposes the research model for research as follows:

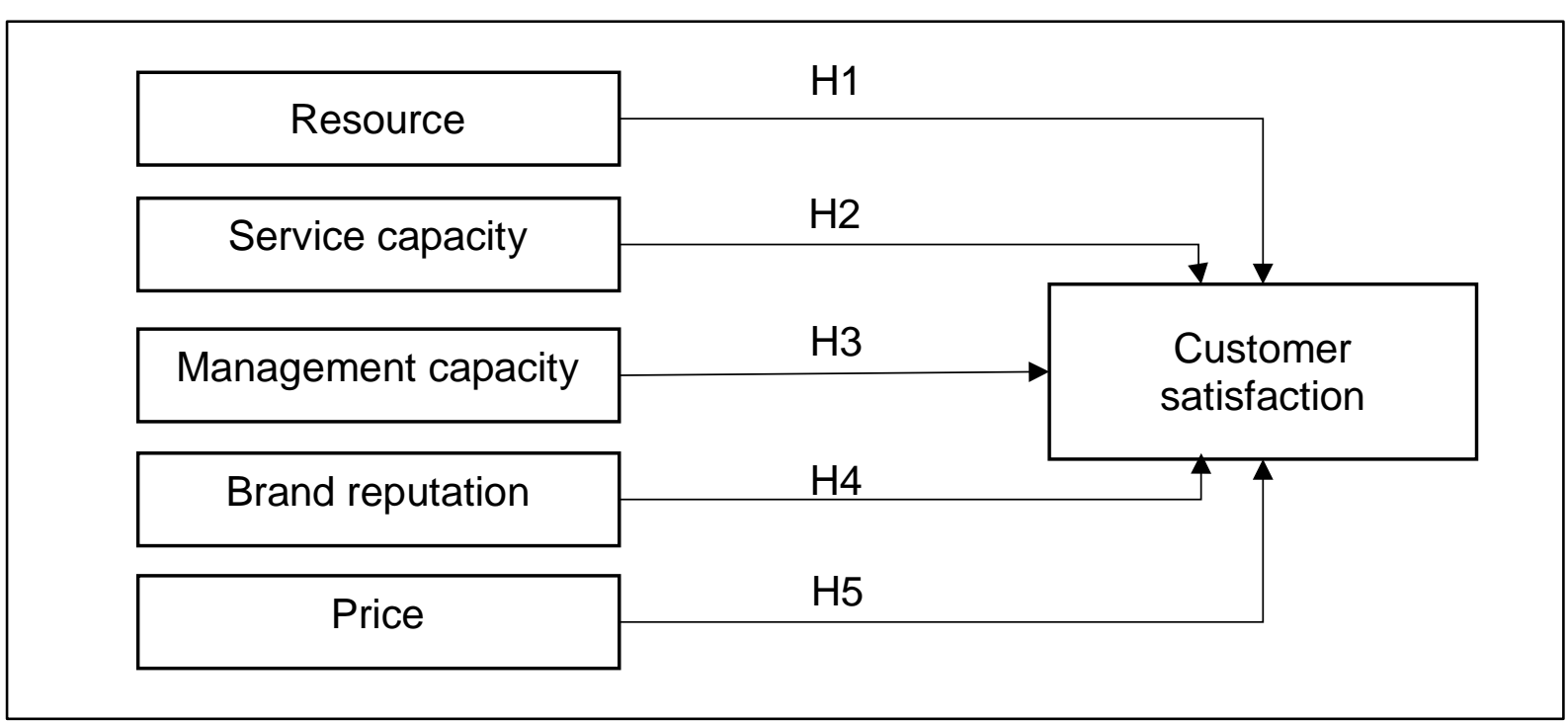

Figure 1: Proposed research model of the authors

According to Tran (2010), the resource factor, including infrastructure, information technology applications, and software for delivery services, has an impact on customer satisfaction. Thai and Grewal (2007) conducted their research on services in the Vietnamese context, and the study found that resources are available elements of equipment, equipment conditions, and the ability to track goods and the infrastructure. 
DOI: 10.14807/ijmp.v11i4.1103

In the previous study of Yang et al. (2009), resources are identified as having a significant positive impact on the ability to provide logistics services leading to improve the business performance of the company. It is also true in research in other areas such as railway transport (NGUYEN; DO, 2013). Therefore, this hypothesis is as follows:

\section{- H1: Resources have a positive effect on customer satisfaction}

Service capacity is expressed through ensuring the commitment in the contract, limiting errors, ensuring goods safety, the accuracy of documents and meeting customers' demands (BUTTLE, 1996; DOAN, 2010; YUEN; THAI, 2015; LY, 2016, TRAN, 2010; PHAM, 2008). Besides, service capacity includes service reliability, speed of service, ensuring the safety of goods, the accuracy of documents, diversity, and service availability is mentioned in the study by Thai and Grewal (2007). According to Parasuraman et al. (1985) argued that the service capacity shows the professional about a specific business to perform services.

\section{- H2: Service capacity has a positive effect on customer satisfaction}

Tran (2010) and Huynh (2013) point out that the management capacity has the most potent effect on customer satisfaction with the quality of delivery services at a shipping company. According to Thai and Grewal (2007), management capacity factors affect customer satisfaction including the application of information technology in management and operation, effective in management and operation, knowledge and skills in solving troubles and accidents, understand customers' needs and requirements; having relationships with suppliers (ports, shipping lines). Therefore, the hypothesis of the research is:

\section{- H3: Management capacity has a positive effect on customer satisfaction}

According to Thai and Grewal (2007), the brand reputation is the prestige and trust of enterprises in the market, and it confirms the brand of business on domestic and world markets. Nguyen and Do (2013) pointed out that the brand prestige has the most effect on customer satisfaction on service quality in a positive direction. Brand reputation factor is created in the process of customer interact with infrastructure, human resources, products, and services (NGUYEN, 2013). Therefore, this study gives the following hypothesis:

\section{- H4: Brand reputation has a positive effect on customer satisfaction}

According to Zeithaml and Bitner (2000), price is what consumers can afford to get the desired products and services. Customers often rely on their perception of the price and feel of what they receive to assess the quality of service they are using. The price factor is expressed 
DOI: 10.14807/ijmp.v11i4.1103

through price competition compared to other companies in the same industry (YUEN; THAI, 2015), price is flexible with market updates (TRUONG, 2015), price is suitable for current requirements as well as deferred payment (PHAM, 2016). Therefore, the study proposes the following hypothesis:

\section{- H5: Price has a positive effect on customer satisfaction}

\section{METHODOLOGY}

This research uses the qualitative research method via group discussions and expert discussions to build research models, scales, questionnaires, and preliminary surveys to complete research models before issuing the questionnaire. The authors surveyed the Vice president of the Vietnam Logistics Business Association (VLA) and surveyed ten members of the Executive Committee of VLA to complete the group discussion.

The quantitative research method was conducted, and it based on information collected from the customer who already uses the cargo delivery services of many famous companies in Vietnam. Likert scale with five levels, namely strongly disagree, disagree, neutral, agree, and strongly agree is used to measure the impact of factors affecting employee satisfaction, and this research uses the convenient sampling method.

Bollen (1989), and Hair et al. (2014) pointed out that when the study uses Likert scale five levels with the $n$ variables, the study should ensure a minimum sample size of $5 * n=5 n$. In the study, the author uses 18 observed scales; a minimum sample size should be $18 * 5=90$.

However, Comrey and Lee (1992) argue that the sample sizes will give the corresponding research results: 50 is very bad, 100 is bad, 200 is pretty good, 300 is good, 500 is very good, and 1,000 is excellent. Because the author added some new scales of the price variable in the study; as a result, to ensure the quality of the sample, the authors decided to distribute a total of 1,800 questionnaires.

In particular, from January to June 2019, this research surveyed 18 prestigious and reputable companies which do cargo delivery service in Vietnam such as: Gemadept Joint Stock Company, DHL Vietnam Global Shipping Company, Saigon New Port Corporation, Viettel Post Corporation, Saigon Port Joint Stock Company, Southern Logistics Corporation, DKSH Vietnam Limited Company, Vietnam Post Corporation, SCHENKER Vietnam Limited Company, Transimex Joint Stock Company, Delta International Limited Company, Southern International Limited Company, LACCO Global delivery and transportation Corporation, 
INDEPENDENT JOURNAL OF MANAGEMENT \& PRODUCTION (IJM\&P)

http://www.ijmp.jor.br

v. 11, n. 4, July - August 2020

ISSN: 2236-269X

DOI: 10.14807/ijmp.v11i4.1103

Hung Thinh Phat Logistics Limited Company, On Time Worldwide Logistics Vietnam Limited Company, Colombus Vietnam Limited Company, PCS Cargo Corporation, SAFWAY Logistics Corporation.

For each company, the author research groups directly distributed the survey questionnaires, and the number of questionnaires for each company was 100 . So after screening data, there were 1,729 valid respondents to be used in the quantitative analysis (accounting for 96.06\%). In quantitative research, the authors use descriptive statistical methods, assessed for reliability through Cronbach's Alpha coefficients, EFA method, and regression to determine factors affecting customer satisfaction in cargo delivery service.

\section{DATA ANALYSIS AND RESULTS}

\subsection{Reliability test: Cronbach's Alpha}

According to Nunnally and Bernstein (1994), the condition to accepting variables is that Corrected Item - Total Correlation is equal or greater than 0.3 and Cronbach's Alpha if item deleted is equal or greater than 0.7. According to Hair et al. (2014), new studies can accept that Cronbach's Alpha if item deleted is equal or greater than 0.6. So, all of the constructs can meet requirements to analyze Exploratory Factor Analysis (EFA).

Table 1: Results of testing the reliability of the scale

\begin{tabular}{|c|l|c|c|}
\hline Items & \multicolumn{1}{|c|}{ Constructs } & \multicolumn{1}{c|}{$\begin{array}{c}\text { Corrected } \\
\text { Item - Total } \\
\text { Correlation }\end{array}$} & $\begin{array}{c}\text { Cronbach's } \\
\text { Alpha if item } \\
\text { deleted }\end{array}$ \\
\hline \multicolumn{1}{|c|}{ Resource - Cronbach's Alpha = 0.783 } \\
\hline RS1 & $\begin{array}{l}\text { The company always has many vehicles to serve } \\
\text { customers' needs }\end{array}$ & 0.629 & 0.708 \\
\hline RS2 & $\begin{array}{l}\text { The company's website has enough information to help } \\
\text { customers find it easily }\end{array}$ & 0.625 & 0.711 \\
\hline RS3 & $\begin{array}{l}\text { Infrastructure, warehouse conditions of the company are } \\
\text { good }\end{array}$ & 0.513 & 0.767 \\
\hline RS4 & Good ability to track the cargo & 0.592 & 0.730 \\
\hline \multicolumn{1}{|c|}{ Service Capacity - Cronbach's Alpha = 0.777 } \\
\hline SC1 & The company provides services as committed & 0.412 & 0.720 \\
\hline SC2 & $\begin{array}{l}\text { The company always ensures the safety for goods (No loss, } \\
\text { loss, damage) }\end{array}$ & 0.631 & 0.616 \\
\hline SC3 & The company always meets customer needs promptly & 0.590 & 0.669 \\
\hline & \multicolumn{1}{|c|}{ Management capacity - Cronbach's Alpha = 0.782 } \\
\hline MC1 & $\begin{array}{l}\text { The company applies information technology in managing } \\
\text { information for customers }\end{array}$ & 0.617 & 0.714 \\
\hline MC2 & $\begin{array}{l}\text { The company always satisfactorily resolves customer } \\
\text { complaints }\end{array}$ & 0.560 & 0.734 \\
\hline MC3 & $\begin{array}{l}\text { Having a good relationship with customs in handling port- } \\
\text { related matters }\end{array}$ & 0.636 & 0.706 \\
\hline MC4 & $\begin{array}{l}\text { Customers feel safe when making transactions with the } \\
\text { company }\end{array}$ & 0.541 & 0.752 \\
\hline & The company is trusted in the market & 0.552 & 0.694 \\
\hline
\end{tabular}


INDEPENDENT JOURNAL OF MANAGEMENT \& PRODUCTION (IJM\&P)

http://www.ijmp.jor.br

v. 11, n. 4, July - August 2020

ISSN: 2236-269X

DOI: 10.14807/ijmp.v11i4.1103

\begin{tabular}{|c|l|c|c|}
\hline BR2 & The company has a famous brand in the market & 0.531 & 0.716 \\
\hline BR3 & Company employees have polite costumes & 0.652 & 0.673 \\
\hline \multicolumn{3}{|c|}{ Price - Cronbach's Alpha = 0.774 } \\
\hline PR1 & $\begin{array}{l}\text { The current price of the company is more competitive than } \\
\text { other companies in the same industry }\end{array}$ & 0.607 & 0.703 \\
\hline PR2 & $\begin{array}{l}\text { The delivery price of the company is flexibly updated } \\
\text { according to the market }\end{array}$ & 0.583 & 0.716 \\
\hline PR3 & $\begin{array}{l}\text { The current price of the company is in line with customer } \\
\text { needs }\end{array}$ & 0.546 & 0.735 \\
\hline PR4 & The company has attractive promotions $\quad$ Customer Satisfaction - Cronbach's Alpha = 0.680 & 0.722 \\
\hline \multicolumn{1}{|c|}{0.572} & 0.618 \\
\hline CS1 & $\begin{array}{l}\text { Feel satisfied when using the company's cargo delivery } \\
\text { service }\end{array}$ & 0.367 & 0.676 \\
\hline CS2 & $\begin{array}{l}\text { Continue to use the company's cargo delivery services in } \\
\text { the future }\end{array}$ & 0.465 & 0.661 \\
\hline CS3 & Introduce the company's cargo services to everyone & 0.497 & \\
\hline
\end{tabular}

\subsection{Exploratory Factor Analysis (EFA)}

Table 2: Result of exploratory factor analysis

\begin{tabular}{|c|c|c|c|c|c|c|}
\hline \multirow{2}{*}{ Concepts } & \multirow{2}{*}{ Items } & \multicolumn{5}{|c|}{ Component } \\
\hline & & 1 & 2 & 3 & 4 & 5 \\
\hline \multirow{4}{*}{ Resourcs } & RS1 & 0.750 & & & & \\
\hline & RS2 & 0.781 & & & & \\
\hline & RS3 & 0.711 & & & & \\
\hline & RS4 & 0.755 & & & & \\
\hline \multirow{4}{*}{ Price } & PR1 & & 0.705 & & & \\
\hline & PR2 & & 0.767 & & & \\
\hline & PR3 & & 0.721 & & & \\
\hline & PR4 & & 0.737 & & & \\
\hline \multirow{4}{*}{$\begin{array}{c}\text { Management } \\
\text { capacity }\end{array}$} & MC1 & & & 0.704 & & \\
\hline & MC2 & & & 0.640 & & \\
\hline & MC3 & & & 0.745 & & \\
\hline & MC4 & & & 0.733 & & \\
\hline \multirow{3}{*}{ Brand reputation } & BR1 & & & & 0.700 & \\
\hline & BR2 & & & & 0.731 & \\
\hline & BR3 & & & & 0.839 & \\
\hline \multirow{3}{*}{ Service capacity } & SC1 & & & & & 0.832 \\
\hline & SC2 & & & & & 0.679 \\
\hline & SC3 & & & & & 0.562 \\
\hline \multicolumn{2}{|c|}{ Eigenvalues } & \multicolumn{5}{|c|}{1.09} \\
\hline \multicolumn{2}{|c|}{ Total Variance Explained } & 14.54 & 28.54 & 42.53 & 54.56 & 64.45 \\
\hline
\end{tabular}

The EFA analysis results show that The Eigenvalues value $=1.09>1$ represents the variation part explained by each factor, the factor that draws the most meaningful information. The total variance extracted value: $64.45 \%$ indicates that five factors explain $64.45 \%$ variation of variables in the data, the model is appropriate - factor loading of all variable is greater than 0.5 , indicating a correlation between variables for representative factors.

\subsection{Regression analysis}


DOI: 10.14807/ijmp.v11i4.1103

Regression analysis finds out the factors that affect customer satisfaction in cargo delivery service and measure the affecting levels of these factors. Before doing the regression analysis, the author does compute the mean value of these factors.

RS: Resource (RS1, RS2, RS3, RS4)

SC: Service capacity (SC1, SC2, SC3)

MC: Management capacity (MC1, MC2, MC3, MC4)

BR: Brand reputation (BR1, BR2, BR3)

PR: Price (PR1, PR2, PR3, PR4)

CS: Customer satisfaction (CS1, CS2, CS3)

The following formula can describe regression analysis model in this research:

$\mathrm{CS}=\beta 0+\beta 1 * \mathrm{RS}+\beta 2 * \mathrm{SC}+\beta 3 * \mathrm{MC}+\beta 4 * \mathrm{BR}+\beta 5 * \mathrm{PR}$

Whereas, CS is dependent variable and it can measure the customer satisfaction in cargo delivery service in Vietnam, and RS, SC, MC, BR, PR are independent variables which can measure the resource, service capacity, management capacity, brand reputation, and price.

Table 3: Regression results

\begin{tabular}{|c|c|c|c|c|c|c|c|c|}
\hline \multirow{2}{*}{\multicolumn{2}{|c|}{ Model }} & \multicolumn{2}{|c|}{$\begin{array}{c}\text { Unstandardized } \\
\text { Coefficients }\end{array}$} & \multirow{2}{*}{$\begin{array}{c}\text { Standardized } \\
\text { Coefficients } \\
\text { Beta } \\
\end{array}$} & \multirow[b]{2}{*}{$\mathbf{t}$} & \multirow[b]{2}{*}{ Sig. } & \multicolumn{2}{|c|}{ Collinearity } \\
\hline & & Beta & $\begin{array}{l}\text { Sd. } \\
\text { Error }\end{array}$ & & & & Tolerance & VIF \\
\hline \multirow[t]{6}{*}{1} & (Constant) & 1.322 & 0.108 & & 12.27 & 0.000 & & \\
\hline & RS & 0.108 & 0.021 & 0.120 & 5.19 & 0.000 & 0.770 & 1.30 \\
\hline & SC & 0.173 & 0.022 & 0.194 & 7.83 & 0.004 & 0.666 & 1.52 \\
\hline & $\mathrm{MC}$ & 0.074 & 0.026 & 0.076 & 2.86 & 0.000 & 0.589 & 1.70 \\
\hline & $\mathrm{BR}$ & 0.193 & 0.023 & 0.212 & 8.50 & 0.000 & 0.658 & 1.52 \\
\hline & PR & 0.147 & 0.025 & 0.141 & 5.96 & 0.000 & 0.730 & 1.37 \\
\hline \multicolumn{4}{|c|}{$\mathbf{F}$} & \multicolumn{5}{|c|}{142.98} \\
\hline \multicolumn{4}{|c|}{ Sig. } & \multicolumn{5}{|c|}{0.000} \\
\hline
\end{tabular}

The $\mathrm{F}$ value $=142.98$ and the sig value of $\mathrm{F}$ is 0.000 , and it is less than 0.05 , so the research model is fit, and the variables which use in the model have a significant statistic. Besides, variance inflation factors (VIF) are too small, and these point out that there is no multicollinearity in this model, so all of the independent variables do not correlate together. What is more, the five variables such as RS, SC, MC, BR, and PR have a significant statistic because the sig of them is less than 0.05 . As a result, these variables affect the satisfaction of land plot sales staffs.

The multiple regression model by standardized coefficients can be identified: 
DOI: 10.14807/ijmp.v11i4.1103

$\mathrm{CS}=0.120 * \mathrm{RS}+0.194 * \mathrm{SC}+0.076 * \mathrm{MC}+0.212 * \mathrm{BR}+0.141 * \mathrm{PR}$

The result from the standardized coefficients and regression model show that the resource, service capacity, management capacity, brand reputation, and price affect customer satisfaction in the cargo delivery service. Besides, these factors positively influence customer satisfaction because the beta of all variables is positive. The result strongly confirms that the price is the new scales that affect customer satisfaction.

\subsection{Hypothesis testing}

Table 4: Hypothesis testing

\begin{tabular}{|c|l|c|}
\hline Hypothesis & \multicolumn{1}{|c|}{ Content } & Result \\
\hline H1 & Resources have a positive effect on customer satisfaction & Accepted \\
\hline H2 & Service capacity has a positive effect on customer satisfaction & Accepted \\
\hline H3 & $\begin{array}{l}\text { Management capacity has a positive effect on customer } \\
\text { satisfaction }\end{array}$ & Accepted \\
\hline H4 & $\begin{array}{l}\text { Brand reputation has a positive effect on customer } \\
\text { satisfaction }\end{array}$ & Accepted \\
\hline H5 & Price has a positive effect on customer satisfaction & Acced \\
\hline
\end{tabular}

\begin{tabular}{|c|c|c|}
\hline & Beta $=0.120$ & \\
\hline \multirow{2}{*}{ Service capacity } & Beta $=0.194$ & \\
\hline & \multirow[b]{2}{*}{ Beta $=0.076$} & 7 \\
\hline \multirow{2}{*}{ Management capacity } & & \multirow{2}{*}{$\begin{array}{l}\text { Customer } \\
\text { satisfaction }\end{array}$} \\
\hline & \multirow[b]{2}{*}{ Beta $=0.212$} & \\
\hline Brand reputation & & \multirow[t]{2}{*}{$\mathbf{T}$} \\
\hline Price & \multirow[t]{2}{*}{ Beta $=0.141$} & \\
\hline 거스. & & \\
\hline
\end{tabular}

Figure 2: Factors affecting to customer satisfaction

\section{CONCLUSION}

\subsection{Conclusion}

Through analysis, the study offers some solutions to increase customer satisfaction with the delivery service of the cargo company. Improving customer satisfaction helps the company retain its current customers as well as attract new customers in the future. Since then, sales for freight delivery in the company will increase, and create sustainable development as well as contribute to increasing competitiveness in the market. It is also the first research on the factors affecting satisfaction for cargo delivery services in Vietnam. 
INDEPENDENT JOURNAL OF MANAGEMENT \& PRODUCTION (IJM\&P)

http://www.ijmp.jor.br

v. 11, n. 4, July - August 2020

ISSN: 2236-269X

DOI: 10.14807/ijmp.v11i4.1103

The author adjusted the scale of service quality - ROPMIS of Thai and Grewa (2007) and the theory of price perception to measure the quality of cargo delivery services. The results show that in the logistics field, all five hypotheses are accepted in this study, bringing a practical meaning to companies that provide freight delivery services. The results of the study help the company to use these measurement scales to determine the factors affecting customer satisfaction, and bases on that the company can have better control and adjustment of these factors. They are thereby increasing the company's customer satisfaction further.

Besides, the research results show that considering each factor, customers achieve the highest satisfaction level for brand reputation when using freight delivery service company. The order satisfaction, in turn, is the service capacity, price, resources and the management capacity factor. Specifically, according to the regression equation: $\mathbf{C S}=\mathbf{0 . 1 2 0} * \mathbf{R S}+\mathbf{0 . 1 9 4} * \mathrm{SC}$ $+0.076 * \mathrm{MC}+\mathbf{0 . 2 1 2} * \mathrm{BR}+\mathbf{0 . 1 4 1} * \mathbf{P R}$, It is clear to see the strongest influence on customer satisfaction is brand reputation $(\beta=0.212)$. The next variables also have a positive effect on customer satisfaction are service capacity $(\beta=0.194)$, price $(\beta=0.141)$, resource $(\beta=0.120)$ and the least affect factor is management capacity $(\beta=0.076)$.

Service quality is the core factor that creates a sustainable development for business in general as well as the cargo delivery business in particular. Therefore, the higher the brand reputation of the company, the better the service quality is assessed by the customer. The brand reputation, which is the strongest influence on customer satisfaction in cargo delivery company is very reasonable. It can be seen that customers can know and use the service that the company is providing is thanks to the brand in the market. The stronger the brand, the higher the trust of customers for the company, thereby contributing to increased satisfaction.

In summary, the study has applied a model to find the factors affecting customer satisfaction on the quality of cargo delivery services at reputation company. The research used the new scale, which is the price to analyze the impact of price on cargo delivery companies in Vietnam.

\subsection{Limitation and future research}

Research has brought merit contributions to the factors affecting the customer satisfaction of the quality of the delivery service at cargo delivery company. However, the research paper has no limitations.

The research surveys the customer in the large sample size $(1,800$ and uses 1,729 for analysis) in Vietnam. The sample size of the research is excellent, but the data collection time 
DOI: 10.14807/ijmp.v11i4.1103

is six months. Therefore, the data used for the analysis is still skewed by time, so the results are not the best. Therefore, when surveying with a large sample size, future research should try to be implemented in a short period of one to two months. It is best for one to two weeks. However, this needs to invest more in finance as well as resources.

Secondly, this study has developed a price scale and confirmed the relationship between price and customer satisfaction in cargo delivery service. However, research has only been conducted in Vietnam. Other research papers may use the results of this study to apply to other countries or other industries related to service quality.

\section{REFERENCES}

BHATNAGAR, R.; SOHAL, A. S.; MILLEN, R. (1999) Third party logistics services: A Singapore perspective. International Journal of Physical Distribution \& Logistics Management, v. 29, n. 9, p. 569-587.

BOJANIC, D. C. (1991) Quality measurement in professional servicer firms. Journal of Professional Services Marketing, v. 7, n. 2, p. 27-36.

BOLLEN, K. A. (1989) Structual Equations with Latent Variables. New York: John Wiley \& Sons.

BUTTLE, F. (1996) SERVQUAL: Review, Critique, Research agenda. Europen Journal of Marketing, v. 30, n. 1, p. 8-32.

COMREY, A. L.; LEE, H. P. (1992) A first course in factor analysis. Hillsdale, NJ: Erlbaum.

CRONIN, J. J.; TAYLOR, S. A. (1992) Measuring Service Quality:A Reexamination and Extension. Journal of Marketing, v. 56, p. 55-56.

DABHOLKAR, P. A. (1996) Consumer evalutions of new technology - based self - service operations: an investigation of alternative models. International Journal of Research in Marketing, v. 13, n. 1, p. 29-51.

DOAN, T. H. V. (2010) Logistics - Basic issues, Labor and Social Publishing House. FORNELL, C.; JOHNSON, M. D.; ANDERSON, E. W.; CHA, J.; BRYANT, B. E. (1996) The American Customer Satisfaction Index: Nature, Purpose nad Findings. Journal of Marketing, v. 60, p. 7-18.

HAIR, F. J.; BACK, C. W.; BABIN, J. B.; ANDERSON, E. R. (2014) Multivariate Data Analysis, London, Pearson.

HUYNH, T. K. (2013) Factors affecting customer satisfaction with logistics services at Kuehne-Nagel Vietnam. University of Economics of Ho Chi Minh City.

KOTLER, P. (2001) Principles of Marketing. Pearson Education Canada.

KOTLER, P.; KELLER, K.L. (2016) Marketing management. Pearson Education Limited. LEHTINEN, U.; LEHTINEN, L. (1982) Service Quality - A Study of Dimensions. Service Management Institute, Helsinki, p. 439-460. 
LOGISTICS BUSINESS ASSOCIATION (2018) Logistics Performance Index (LPI) of Vietnam in 2018 increased by 25 grades. Retrieved from http://vlr.vn/logistics/news3735.vlr

LY, T. (2016) Improving logistics service quality in cargo in Ho Chi Minh city, Vietnam. Thesis, Helsinki Metropolia University of Apllied Sciences.

NGUYEN, T. D. (2013) Measuring customer satisfaction on quality of UPS Vietnam in cargo services. University of Economics of Ho Chi Minh City.

NGUYEN, T. L. A.; DO, T. T. V. (2013) Improving the quality of rail transport support services at Nha Trang station - Khanh Hoa province. Journal of Fisheries Science and Technology, Nha Trang University.

NUNNALly, C.; BERNSTEIN, I. H. (1994) Psychometric theory, New York, McGrawHill Company.

OLIVER, R. L. (1997). Satisfaction - A Behavioural Perspective on the Consumer. New York: McGraw-Hill.

PARASURAMAN, A.; ZEITHAML, V. A.; BERRY, L. L. (1985) A conceptual Model of Service Quality and Its Implications for Future Research. Journal of Marketing, v. 49, n. 4, p. 41-50.

PARASURAMAN, A.; ZEITHAML, V. A.; BERRY, L. L. (1988) SERVQUAL: A multiple - Item scale forr measuring cunsumer preceptions of service quality. Journal of Retailing, $v$. 64, n. 1, p. 12-40.

PHAM, H. G. (2016) Factors affecting customer satisfaction with sea freight forwarding services, case studies of Kintetsu World Express (Vietnam) Co., Ltd., Ho Chi Minh City branch. University of Economics of Ho Chi Minh City.

PHAM, T. M. H. (2008) Relationship between port service quality and customer satisfaction and satisfaction in Ho Chi Minh City. University of Economics of Ho Chi Minh City.

PITT, L. F.; WATSON, R. T.; KAVAN C. B. (1995) Service Quality: A measure of Information Systerms Effectiveness. MIS Quarterly, v. 19, n. 2, p. 173-187.

THAI, V. V. (2007) Service quality in maritime transport: conceptual model and empirical evidence, Asia Pacific Journal of Marketing and Logistics, v. 20, n. 4, p. 493-518.

THAI, V. V. (2015) The Impact of Port Service Quality on Customer Satisfaction: The Case of Singapore. Thesis, Namtang Technological University, Singapore.

THAI, V. V.; GREWAL, D. (2007) An analysis of the efficiency and competitiveness of Vietnamese port systerm. Asia Pacific Journal of Marketing and Logistic, v. 17, n. 1, p. 331.

TRAN, T. K. (2010) Researching customer satisfaction with quality of import and export goods delivery service at small and medium sized at cargo companies in Vietnam - Case study at TNNH VIETLINK. University of Da Nang, Ho Chi Minh City.

TRUONG, T. B. N. (2015) Study the factors affecting customer satisfaction with the quality of Logistics services at T\&A Company Limited. University of Finance Marketing.

TSE, D. K.; WILTON, P. C. (1988) Models of consumer satisfaction formnation: An extension. Journal of Marketing Research, v. 25, p. 204-212. 
DOI: 10.14807/ijmp.v11i4.1103

WORLD BANK (2018). Global ranking on Logistics Performance Index (LPI). Retrieved from https://lpi.worldbank.org/international/global

YANG, H. E.; WU, C. C.; WANG, K. C. (2009) An empirical analysis of online game service satisfaction and loyalty. Expert Systerm with Applications, v. 36, n. 2, p. 18161825.

YUEN, K. F.; THAI. V. V. (2015) Service quality and customer satisfaction in liner shipping. International Journal of Quality and Service Sciences, v. 7, n. 2/3, p. 170-183.

ZEITHAML, V. A.; BITNER M. J. (2000) Services Marketing: Integrating Customer Focus across the firm. New York: McGraw-Hill. 